\title{
e-Assessment for learning and performativity in higher education: A case for existential learning
}

\author{
Jennifer Charteris, Frances Quinn, Mitchell Parkes, Peter Fletcher, Vicente Reyes \\ University of New England, Armidale, Australia
}

This paper provides a critical and contextualised exploration of assessment for learning (AfL) as an important area of scholarship in higher education, particularly in online learning environments. Although AfL can speak to a range of education discourses, the specific focus here is on the performativity and experiential learning discourses around individual and collective notions of AfL in online settings (e-AfL). We argue that e-AfL practices that emphasise performativity and are used primarily for technicist purposes impoverish their potential to promote learning. We explore the existential notion that e-AfL can transcend formulaic and procedural interpretations of formative assessment in higher education. Rich, divergent approaches to e-AfL can support students in higher education courses to develop their funds of identity, thereby enhancing learner reflexivity and agency.

\section{Introduction}

Given the widespread adoption of distance and blended learning opportunities in higher education (HE), research attention is turning to the issue of assessment for learning (AfL) in online environments, that is, eassessment for learning (e-AfL) (Jordan \& Mitchell, 2009). Much recent research focuses on specific AfL practices in $\mathrm{HE}$ and the particular technologies, tools, and techniques that facilitate them. While scholarship of this aspect of teaching and learning is extremely valuable, in this paper we take a wider socio-cultural approach and draw from contemporary literature in the sociology and philosophy of education, to explore some underpinning discourses that both reflect and influence the particulars of how AfL might be conceptualised and enacted in higher education online settings. A Foucauldian perspective suggests that discourses construct regimes of truth that regulate how people perceive themselves, each other and the world (Foucault, 2007). Critically examining dominant assessment discourses allows us to probe the limitations and affordances of AfL in online HE settings, and hence further inform the choices from an array of technological and pedagogical options that are available to educational developers and other practitioners of teaching in HE.

Considerations and conceptions of AfL reflect different ideas of what education is for. It has been suggested that education, at least within Knowledge Age discourse, “must foreground the development of learners' dispositions, capacities or competencies to deal with new situations and environments, including those with high degrees of complexity, fluidity and uncertainty” (Bolstad, Gilbert, McDowall, Bull, Boyd, \& Hipkins, 2012; p. 2). This discourse suggests that economic development is premised on the capacity of new knowledge creation and the potential value added by innovation. Central in this kind of education is developing learner reflexivity (Edwards, Ranson, \& Strain, 2002) and agency. Here we view reflexivity as a form of critical introspective questioning of self and society (e.g., Edwards, Ranson, \& Strain, 2002), and agency as the "the capacity of actors to critically shape their own responsiveness to problematic situations" (Emirbayer \& Mische, 1998; p. 971). These are crucial dispositions for learners in HE, who need to be critical thinkers and active, deep learners able to deal with complexity, fluidity and uncertainty.

The extent to which AfL practices in online environments are commensurate with the kind of education that supports reflexivity and agency is dubious. AfL is often linked with quality teaching practice that can enhance learning and achievement in HE online settings (Boud \& Associates, 2010; Boud \& Molloy, 2013; Nicol, 2009; Pryor \& Crossouard, 2010). Some examples of these quality teaching practices relate to the levels of interactivity among online participants that somehow influence the effectiveness and efficiency of formative feedback (van der Pol, van den Berg, Admiraal, \& Simmons, 2008) and instances where detailed and clearly-written feedback is integrated into the work of students (Wolsey, 2008). However, a dominant aspect in the literature on learning in HE, both in distance and blended contexts, is a discourse that focuses on transmissive feedback as quality formative e-assessment (Stödberg, 2012). This kind of assessment is exemplified by learning objects or quizzes which certainly have an extremely useful and important place in online learning environments. These techniques can enable timely and specific teacher-student feedback, 
and if well designed, allow students and teaching staff to recognise areas of relative strength and also difficulties, in time to focus their efforts and attention most usefully. They can engage learners to be selfregulating by enabling them to evaluate their own mastery of content and in the process help them assume a more direct and pivotal role in their learning (Gikandi, Morrow, \& Davis, 2011). Although we acknowledge the value of these tools we also contend that overreliance on such transmissive approaches does not facilitate or engender learner reflexivity or agency. We argue that transcending such transmissive e-AfL has the potential to better afford reflexivity and agency, and therefore enhance the learning that might be possible in online environments.

Therefore we advance a conception of e-AfL that is both reflexive and existential. We use the term existential to frame ways in which young people make sense of being in and with the world (Biesta, 2015) and, in particular, how selves are located and produced within specific social cyber contexts. We can see existentialism working through social media like Facebook, or ephemeral media like Snapchat, where youth engage in relational contexts and construct selves through connecting with their networked publics (Boyd, 2010). Further, learning as existential is "rich and meaningful [and] consists not only in the materiality or the social construction of the environment, but also in the embodied and affective ... connection between learners and the place” (Hung, 2014; p. 1140). Becker-Lindenthal (2015) argues in her article on massive open online courses (MOOCs), for teachers to be facilitators of existential learning where they take up positions other than knowledge expert, providing a "challenging, yet supportive environment [as a] 'safe space’ for students’ self-expression and interaction with each other” (p. 321).

This article proceeds with a discussion of the important relationships between AfL and formative assessment (FA), followed by an exploration of how in HE settings these interrelated concepts can be interpreted from the discourse positions of performativity and existential learning. We conclude with the recognition of e-AfL practices that promote learner decision-making, and ownership of learning processes that support the development of learner identities, reflexivity and agency.

\section{The relationship between AfL and FA}

In this article we are focussing on assessment that is formative in nature. This is not because summative assessment is unimportant, as indeed both forms of assessment are closely linked. Summative assessment can be used dynamically for formative purposes (Black, Harrison, Lee, Marshall, \& Wiliam, 2003; VadenGoad, 2009), and of course FA can enhance summative outcomes (Miller, 2009). However, it is important to note that rather than framing kinds of assessment, the terms summative and formative reflect the use made of information arising from assessments (Wiliam \& Black, 1996).

The terms AfL and FA are used in diverse ways, and the relationship between them also varies in the literature. Some writers use the terms AfL and FA synonymously (Glasson, 2008; James et al., 2007; Wiliam, 2007), while others differentiate between the terms FA and AfL (Chappuis \& Chappuis, 2008; Stiggins, 2005). We observe that FA has been taken up in university settings as an individualistic process where there is a focus of the learner's metacognitive engagement with classroom material (Niedwiecki, 2013). We are in accord with Klenowski (2009), who reports a second generation definition of AfL, which is embedded in the "everyday practice by students, teachers and peers that seeks, reflects upon and responds to information from dialogue, demonstration and observation in ways that enhance ongoing learning" (Klenowski, 2009; p.2). This definition constructs AfL as a sociocultural concept: an interpretation that came into vogue following Gipps' (1994) distinction of AfL from assessment of learning (Pryor \& Croussard, 2005). Sociocultural theory offers a view of learning as a social practice of identity development, and AfL can be a situated practice (Lave \& Wenger, 1991) where learners activate each other's learning as instructional resources for each other (Wiliam, 2011). Examples of such practice could include marking rubrics that are negotiated or co-constructed between lecturer and students, or that are used by students and lecturing staff in discursive ways to enhance their learning, discussion board dialogue, peer and group assessment practices, sharing of assignments, and collaborative discussion board submissions.

The hybridisation of FA and elearning has been given a range of related terms in the literature including formative online assessment (Einig, 2013), formative e-assessment (Walker, Topping, \& Rodrigues, 2008) and e-assessment for learning (Jordan \& Mitchell, 2009). Formative e-assessment can be described as "multiple processes involving technologies to greater or lesser degrees, where evidence is generated about 
a learner's state of understanding relative to desirable goals, and where individuals are enabled to take actions which have formative effects” (Daly, Pachler, Mor, \& Mellar, 2010; p. 634). As suggested by Gikandi, Morrow and Davis (2011), formative e-assessment includes characteristics that differ from faceto-face contexts due to the often asynchronous nature of the participants' interactivity. Scoping for an existential conception of learner development, we recognise e-AfL as a sociocultural process potentially facilitating identity development in HE, with the potential to be a democratic and divergent process.

A range of discourses is manifest in AfL literature. We focus here specifically on two key discourses: performativity and existential learning, both of which are important in considering how AfL is constituted in online/blended HE settings.

\section{Performativity: (e-)AfL and the self-governing learner}

Learning as performativity as characterised by Lodge (2002), has a focus on external evaluation, ticking boxes, public recognition, and is teacher-centred with the teacher as the evaluator. In Australia, there is focus on HE teacher quality that can be aligned with a discourse of performativity (see Ball, 2003). Fuelled by international comparison data and the drive for economic competition, Australian universities are charged with raising teacher standards, and monitoring and documenting teacher performance through various student and peer evaluation, benchmarking, and performance reviews.

AfL is clearly linked with the performative concept of continuous improvement (James \& Biesta, 2007) as a ubiquitous element and key driver of reform in both the HE and schooling sectors. For example, the Assessment 2020 initiative (Boud \& Associates, 2010) begins with the statement, "[u]niversities face substantial change in a rapidly evolving global context” (p. 1), emphasising the role of global competition and the need for innovation and improvement in relation to HE assessment practice. AfL is embedded within the institutional change agenda of Australian universities and arguably in education further afield. The UK based Learning how to Learn project highlighted the powerful influence of AfL on student learning, and framed significant reform in the schooling sector (James et al., 2007).

Performativity constructs a sophisticated mode of social and cultural control. Ball (2003; p. 221) explains how day-to-day educator practice is flooded with a "baffling array of figures, indicators, comparisons and forms of competition." This causes "values schizophrenia” (p. 221) for teachers who strive to reconcile their commitment to their students and their necessity to be seen to "perform" well. He suggests that there is “a potential 'splitting' between the teachers' own judgments about 'good practice' and students' 'needs' and the rigours of 'performance”” (Ball, 2003, p. 221). As Ball (2003) outlines:

Performativity is a technology, a culture and a mode of regulation that employs judgments, comparisons and displays as means of incentive, control, attrition and change based on rewards and sanctions (both material and symbolic). The performances (of individual subjects or organizations) serve as measures of productivity or output, or displays of "quality", or "moments" of promotion or inspection. As such they stand for, encapsulate or represent the worth, quality or value of an individual or organization within a field of judgment. The issue of who controls the field of judgment is crucial. (p. 216)

Although there are various elements of the performativity narrative that we view as problematic, we take up three particular elements in order to frame how they are enacted through practices associated with eAfL. These are their relationship to governmentality, pastoral control, and the kind of learning encouraged by e-AfL pedagogy. We see these elements as particularly important to scrutinise because of their potential influence on the kinds of transmissive e-AfL practices that are so readily afforded by current technologies.

The first of these issues is the relationship of performative e-AfL discourse with governmentality, through emphasis on self. Governmentality as the "art of government” (Foucault, 2007; p.108) describes social control in relation to to a political rationality that underpins the use of technologies of power (Peters, 2009). The development of self-governing, lifelong learners feeds into the notion of global competitiveness alluded to by Pryor and Crossouard (2008) where the neoliberal citizen is a competitive, self-regulating individual. The self theories of cognitive psychology - self-control, self-management and self-regulated learning can be interpreted as liberal humanist notions that support governmentality. In HE "the self-interest of the 
academic [or individual learner] is re-constituted in terms of the interest of the university, and the selfinterest of the university translates back into the interest of the academic [or learner]" (Davies \& Bansel, 2010; p .9). The learner is constituted as a self-interested customer, and teaching is providing a service to credential individual learners in competition, to the detriment of broader educational goals that focus on the "critical learning, ethical deliberation and civic engagement” (Giroux, 2003; p. 196).

Hence performative e-AfL discourse can be seen as a form of governmentality in that it supports the development of self-surveilling citizens who can manage themselves in accordance with the operations of the state, such as the schooling sector, HE and the workforce. Much assessment literature and practice draws on the self theories; such as self- evaluation, for example, through self-assessment (e.g. Falchikov \& Boud, 1989) and self-regulation, for example, through students setting their own assessment goals (e.g. Boekaerts \& Corno, 2005) from a range of digitally presented alternatives, or diagnosing their own gaps in knowledge through automated feedback from online quizzes. Moreover, there is evidence that the processes of developing self-awareness, self-monitoring, and self-evaluation are critical elements for effective selfregulation and performance (Kibble et al., 2011; p. 129). A technical rational perspective, where there is a linear focus on performance, plugging gaps and responsibility devolved out to the learner, is exemplified in the following extract from Palmer and Devitt (2014).

Formative assessment is designed to inform both student and teacher about the progress of the student. Student use of formative assessment exercises is intended to create awareness of their own weaknesses in order to formulate plans to address them. When well designed, a formative assessment process should reduce students' dependence on the teacher but, through good feedback, the teacher will still play an important role. (p. 1)

This connection made between the individualistic self-regulatory e-AfL practices and performance emphasises the relationship between self-theories of cognitive psychology as a neoliberal humanist operation of performativity. While we acknowledge the value in e-AfL practices that enhance learner selfregulation and self-evaluation, we also see a danger in uncritically adopting the learner-self lens in e-AfL. What the self lens leaves out of focus is the social, participative nature of learning that enhances learner reflexivity and agency, and that depends on more dialogic and collaborative conceptions of e-assessment. Existentialist notions of learning can be linked with the situated notion of selves in relation to others.

The second point we would make in relation to the performativity discourse is that although the notion of collaborative and peer e-AfL can appear democratic and inclusive, from a Foucaldian perspective it can also be a very efficient exercise in pastoral control (Schultz, 2004). Pastoral control encapsulates how control can be disseminated through networks of participants. In the context of e-AfL in HE this can be through an individual/social interface in where learners can act as instructional resources for each other (Wiliam, 2011), for example, through collaborative or peer learning and assessment, monitoring each others' discussions and user-generated content. However, teachers in most cases still ultimately control the learning and assessment activities, quality criteria and the online rules of engagement, but this control is exercised less directly, and less visibly at arm's length, through the mutually reinforcing activities and buyin of the learners.

While on the surface, pastoral control appears to be an egalitarian construct, an alternative reading suggests performativity. In describing pastoral control, Gee, Hull and Lankshear (1996; p. 7) point out that workers are "asked to think and act critically (but not too critically), reflectively, and creatively", investing their "hearts, minds, and bodies fully in their work". They go on to suggest that "while this offers a less alienating view of work and labour, in practice it can amount to a form of mind control and high-tech, but indirect coercion” (Gee, Hull, \& Lankshear, 1996; p. 7). This important critique of pastoral control when applied to e-AfL provides an induction into sophisticated mechanisms of pastoral control that can be deployed in other workplace settings. Schutz (2004) describes how elaborate forms of social control that defy critique or resistance are operationalised in education settings where pastoral mechanisms of sociocultural control prevail.

They teach each other the correct way to participate. Unlike traditional settings that tend to sanction divergences from a static norm, then, pastoral settings foster particular forms of creativity, often harnessing them to serve the (loosely coupled) systems in which participants 
are enmeshed. And because control ... is distributed throughout the environment instead of located in (apparently) identifiable figures or systems, it is extremely difficult for participants to detect or resist. (Schutz, 2004; p.15)

The (by and large) invisibility of this form of control speaks to persistent and problematic philosophical issues in education, such as the tensions between indoctrination and empowerment, and the normative purposes of education. Along the lines posited by Schultz (2004), if a purpose of education includes combatting inequality, this arguably entails students learning how to contest and resist domination and social control, and suggests the importance of educators being at least aware of their own exercise of pastoral control through e-AfL practices.

The third point pertinent to the performativity discourse relates to the kind of learning encouraged by some e-AfL practices. The provision of FA as digitally transmitted feedback from teacher to student can be continuously embedded in the teaching and learning process of a HE curriculum (Lin \& Lai, 2013). Automated responses enable formative e-Assessment feedback to be delivered instantaneously, and instant digital feedback tools attached to electronic quizzes, closed answer tests and the like are almost ubiquitous in online HE contexts. Online provision of FA as multiple-choice questions easily meets the performativity imperatives of feasibility and cost effectiveness (Kibble et al., 2011; Mackey, Derr, \& O'Connor, 2009). Velan, Jones, McNeil and Kumar (2008) report that in their biomedical science context, automated online FAs were not only popular with their students, but that the sizeable effort and expense in setting up the online FAs was justifiable because they were popular, and seemed to help enhance learning outcomes.

So in many ways such transmissive and convergent e-AfL is a very appealing approach for academics. On the one hand, it potentially frees them to support and interact with students in more meaningful ways, such as "supporting students in the light of misunderstandings highlighted by the e-assessment questions or in marking questions where the sophistication of human judgment is more appropriate" (Jordan \& Mitchell, 2009; p. 383). On the other hand, investing these time savings into research-related activity rather than more meaningful teaching can also be very alluring to academics juggling heavy workloads, and who are under pressure to publish or perish in a global knowledge era, where academic work is performative and commodified.

While Jordan and Mitchell (2009) note that these assessment tools provide an opportunity for students to take action to close the gap between their current level and a reference point, they suggest this raises a concern that conventional e-assessment tasks can encourage a surface approach to learning. This is not new. Closed convergent assessment formats such as those predominating on online tests and quizzes have for decades been criticised for encouraging surface learning (e.g. Biggs 2001), which often leads to impoverished learning outcomes (Prosser \& Trigwell, 1999). Likewise, Hodgson and Pang (2012) observe that digital instant feedback tools with their convergent close-ended answers, can be too narrowly focused to engage students with deep learning. Although their conceptualisation of convergence is much wider than automated e-AfL feedback (which would be at the extreme end of their convergent/divergent continuum), Pryor and Crossouard (2008) make the point that while convergent assessment in HE is both inevitable and desirable in relaying the curriculum, FA needs to move constantly between convergent and more divergent discursive practices to also attend to learner agency. This suggests the need to augment the ubiquitous convergent e-AfL with more existential learning and assessment experiences.

\section{Existential learning}

We adopt Jarvis's (2006) definition of existential learning where an individual's body, mind and social situational experiences are "transformed cognitively, emotively, or practically" with the result of a “continually changing (or more experienced) person” (p. 134). Existential learning comprises the personal and affective expression of selves. It can be experienced through relational interactions in online communities. Sociocultural perspectives on student learning offer a useful lens through which to explore the more existential aspects of learning discourse. The term sociocultural encompasses a range of theoretical perspectives that share an interest in relations among the person, activity, and situation, as they are given in social practice (Lave, 2009). Sociocultural theory illustrates the discursive relationships between human mental functioning and the cultural, institutional, and historical situations where it occurs (Wertsch, del Rio, \& Alvarez, 1995). Hence learning cultures comprise the social practices through which 
people learn, rather than just the context or environment where learning takes place (Hodkinson, Biesta, \& James, 2008). Wenger's (2011) model Communities of Practice (CoP) embodies such a principle. Wenger defines a CoP as "people who engage in a process of collective learning in a shared domain of human endeavor" (p. 1). This is an important difference in that it challenges the notion of learning as a set of outcomes or products of a particular culture.

As mediated tools that can broker identities online, technologies are inherent in the mediation of learning cultures and the development of CoPs. A sociocultural interpretation of e-AfL can embed the purposeful use of elearning technologies in HE to support learner identities. Pryor and Crossouard (2010) construct a taxonomy that has implications for learning cultures in HE. They define four purposes for FA: completing the task in hand, thinking about improvement, making sense of criteria, and invoking learner identities (Table 1).

Table 1

The purposes of formative assessment (Pryor \& Crossouard, 2010; p. 270)

\begin{tabular}{|c|c|c|c|}
\hline Completing the task in hand & レヤ & How can $\mathrm{I} /$ we get this done? & Concrete/procedural \\
\hline \multirow[t]{3}{*}{ Thinking about improvement } & & How can I get this done well? & \\
\hline & & How might I do this better? & \\
\hline & & How did I do that? & \\
\hline \multirow[t]{4}{*}{ Making sense of criteria } & & What does better mean? & Reflective/discursive \\
\hline & & Who decides that? & \\
\hline & & Why do they think it is better? & \\
\hline & & $\begin{array}{l}\text { How does this relate to power } \\
\text { issues? }\end{array}$ & \\
\hline \multirow[t]{3}{*}{ Invoking learner identities } & & How am I implicated in this? & Discursive/existential \\
\hline & & $\begin{array}{l}\text { How does this relate to my } \\
\text { identities (past present and } \\
\text { future)? }\end{array}$ & \\
\hline & & $\begin{array}{l}\text { Who am I? Who do I wish to } \\
\text { be? }\end{array}$ & \\
\hline
\end{tabular}

The taxonomy outlined in Table 1 is designed as a resource that the authors suggest could entice academics into thinking more specifically and organically about pedagogies that are more appropriate to pedagogically and technologically evolving twenty-first century HE. Deploying the table as a heuristic for HE settings, eAfL can be seen to "involve movement across a concrete-procedural-reflective-discursive-existential continuum, and between the convergent and divergent” (Pryor \& Crossouard, 2010; p. 256). The concrete/procedural dimension could be exemplified by e-AfL that gives narrow procedural feedback on how to approach a task. If focussed on exclusively, this concrete/procedural and pragmatic kind of e-AfL can reflect a less sophisticated conception of learning and a preoccupation with performativity. Shifting into reflective/discursive and discursive/existential dimensions we see engagement with purposes for education that link with citizenship and the collective social good. Biesta (2006) alludes to existential discourse in the way that he constructs the role of the educator as a creative process of shaping subject positions. To be an educator is, "to treat the question of what it means to be human as a radically open question, a question that can only be answered by engaging in education rather than as a question that needs to be answered before we engage in education” (Biesta 2006; pp. 4-5). Furthermore, Biesta (2006) argues that educators should not be seen as midwives engaged in the "production of the rational autonomous individual” (p. 9), rather they create a world that supports "the coming into presence of unique subjects" (p. 49) through asking difficult questions and creating difficult encounters that disrupt settled discourses and practices.

A sociocultural conception of e-AfL in HE facilitates existential learning as identity work. Individualistic online FA practices offer a focus on the learners' engagement with classroom material and epedagogy that extends support to learners. A wider sociocultural conception of e-AfL transcends this focus through 
actively engaging students in driving their own and each others' learning within a CoP. While there are studies on online FA practices that take a cognitive view of learning and explore notions of individual knowledge acquisition and self-regulation (Velan et al., 2008), little has been written from a situative position where e-AfL practices potentially impact on learning as identity development within a community of learners. Turkle (1996) notes that an online environment "gives people the chance to express multiple and often unexplored aspects of the self, to play with their identity and to try out new ones” (p. 12). Lafuente, Remesal and Álvarez Valdivia (2014) describe how learning can be facilitated in online settings that support sociocultural practices of negotiating meaning and increased learner autonomy. They highlight that it is important to acknowledge the impact of support patterns on students' learning. Sawyer (2002) points out that a sociocultural position suggests transformation of the social practices of the entire group and thus analysis of learning cannot be reduced to an analysis of what any one participant in the group does or knows. Current predominant performance metrics are of limited value in this kind of learning.

Learning can influence how we see the world and, in turn, see ourselves. From a sociocultural perspective, Pryor and Croussard (2008) challenge the notion that learning is solely the acquisition and possession of knowledge. They pose a question whether it is "a contextualised performance involving students engaging with prospective and current social identities, and therefore is an ontological as well as an epistemological accomplishment?” (p. 265). Taking a similar stance, Biesta (2007) highlights how although knowledge in the industrial age has always had a loose link with the economy, in recent years it has become more closely aligned, and that HE itself is a commodity. Thus the knowledge economy with its primary focus on competition and individualism can be seen to undermine a focus on difference, deep learning and democratic participation. We suggest that e-AfL could be enacted to better engage learners in existential processes: to help young people see and be in the world, and to enhance their sense of who they are.

In this sense, the term e-AfL foregrounds the importance of learner assessment literacy (Stiggins, 1991; 2014) as an important capacity to develop in its own right. We use the term assessment literacy as a process of gathering rich, varied and dependable evidence of student achievement through the use of assessment processes that both support and certify student achievement depending on the context (Stiggins, 2014). Assessment literacy is relevant to HE students in digital contexts if they are to take an agentic role in their own elearning and understand e-assessment processes through the medium of technology.

Effective e-AfL environments embrace what Esteban-Guitart and Moll (2014; p. 31) describe as students’ "funds of identity": the historically, culturally and socially accrued resources that people use to define, express and understand themselves. Existential e-AfL that evokes funds of identity can be facilitated through dialogic feedback that draws on and honours learners' lifeworlds and funds of knowledge. Forbes (2005) argues that formative interaction in asynchronous online discussions can be an elemental component of effective teaching and learning. Deploying the term formative interaction, Forbes (2012) highlights the interactive nature of formative processes, emphasising that both teachers and students are actively involved. She points out that through their interactions in asynchronous online discussion forums, opportunities can be generated for enhancing students' learning and understandings. Forbes' conception is a generative environment in that her research describes a learning culture where students generate feedback about their learning.

This kind of e-AfL positions learners as agentic and de-centres the power of the instructor in elearning environments. Due to the nature of elearning technologies, this decentring is increasingly possible through the development of high-agency student-centred learning environments. These afford student choice in learning and assessment tasks, for example, through user-generated content and design, synchronous and a-synchronous multi-way communication, and different multimodal possibilities for soliciting and representing understandings. Thus e-AfL might be seen as a means of learner empowerment.

\section{Conclusion}

The review of literature indicates that e-AfL draws from a range of perspectives. Clearly, a key issue is purpose, and where procedural knowledge is required, transmissive approaches to feedback can support learners to engage with knowledge - although deeper engagement with meaning making may be uncertain. However, we contend that thinking also needs to be centred around e-AfL practices that promote learner decision-making, understandings of learning to learn, learner ownership of learning processes and the 
development of learner identities. The authors advocate engagement with the discourses that underpin eAfL pedagogies as a shift away from practices that emphasise performativity, the commodification of knowledge and neoliberal conceptions of learning. We are promoting e-AfL practices that serve to enhance learner reflexivity and agency by affording the development of funds of identity, and engagement with the existential question of "Who am I?". Assessment discourses play an important role in the subjectification of participants and it is important that tertiary educators recognise how these influences play out through pedagogical practice. We view that e-AfL can be evaluated in light of Pryor and Crossouard's (2010) taxonomy, particularly in relation to the enhancement of learner reflexivity, agency and identity.

\section{References}

Ball, S. (2003). The teacher's soul and the terrors of performativity. Journal of Education Policy, 18(2), 215-228. http://dx.doi.org/10.1080/0268093022000043065

Becker-Lindenthal, H. (2015). Students' impression management in MOOCs: An opportunity for existential learning? MERLOT Journal of Online Learning and Teaching, 11(2), 320-330. Retrieved from http://www.jolt.merlot.org/Vol11no2/Becker_0615.pdf

Biesta, G. (2006). Beyond learning: Democratic education for a human future. Boulder, CO: Paradigm Publishers.

Biesta, G. (2007). Towards the knowledge democracy? Knowledge production and the civic role of the university. Studies in Philosophy and Education, 26(5), 467-479. http://dx.doi.org/10.1007/s11217$\underline{007-9056-0}$

Biesta, G. (2015). Freeing teaching from learning: Opening up existential possibilities in educational relationships. Studies in Philosophy in Education, 34(3), 229-243. http://dx.doi.org/10.1007/s11217014-9454-Z

Biggs, J. B. (2011). Teaching for quality learning at university: What the student does. United Kingdom: McGraw-Hill Education.

Black, P., Harrison, C., Lee, C., Marshall, B., \& Wiliam, D. (2003). Assessment for learning: Putting it into practice. Buckingham: Open University Press

Boekaerts, M., \& Corno, L. (2005). Self-regulation in the classroom: A perspective on assessment and intervention. Applied Psychology, 54(2), 199-231. http://dx.doi.org/10.1111/j.14640597.2005.00205.x

Bolstad, R. and Gilbert, J., with McDowall, S., Bull, A., Boyd, S., and Hipkins, R. (2012). Supporting future-oriented learning and teaching: A New Zealand perspective. Wellington: Ministry of Education. Retrieved from http://westernsprings.school.nz/New\%20School/becoming_a_new_school/Resources/Bolstad_Gilbert FutureOriented.pdf

Boud, D., \& Associates (2010). Assessment 2020: Seven propositions for assessment reform in higher education. Sydney: Australian Learning and Teaching Council. Retrieved from http://www.uts.edu.au/sites/default/files/Assessment-2020_propositions_final.pdf

Boud, D., \& Molloy, E. (2013). Rethinking models of feedback for learning: The challenge of design. Assessment \& Evaluation in Higher Education, 38(6), 698-712, http://dx.doi.org/10.1080/02602938.2012.691462

Boyd, D. (2010). Social network sites as networked publics: Affordances, dynamics, and implications. In Z. Papacharissi (Ed.), A networked self: Identity, community, and culture on social network sites (pp. 39-58). New York, NY: Routledge

Chappuis, S., \& Chappuis, J. (2008). The best value in formative assessment. Educational Leadership, 65(4), 14-18. Retrieved from http://www.k-state.edu/ksde/alp/resources/Bibliography-Module18.pdf

Daly, C., Pachler, N., Mor, Y., \& Mellar, H. (2010). Exploring formative e-assessment: Using case stories and design patterns. Assessment \& Evaluation in Higher Education, 35(5), 619-636. http://dx.doi.org/10.1080/02602931003650052

Davies, B., \& Bansel, P. (2010). Governmentality and academic work: Shaping the hearts and minds of academic workers. Journal of Curriculum Theorizing, 26(3), 5-20. Retrieved from http://journal.jctonline.org/index.php/jct/article/download/250/85

Edwards, R., Ranson, S., \& Strain, M. (2002). Reflexivity: Towards a theory of lifelong learning. International Journal of Lifelong Education 21(6), 525-536.

http://dx.doi.org/10.1080/0260137022000016749 
Einig, S. (2013). Supporting students' learning: The use of formative online assessments. Accounting Education: An International Journal, 22(5), 425-444. http://dx.doi.org/10.1080/09639284.2013.803868

Emirbayer, M., \& Mische, A. (1998). What is agency? American Journal of Sociology, 103(4), 962-1023. http://dx.doi.org/10.1086/231294

Esteban-Guitart, M., \& Moll, L. (2014). Funds of identity: A new concept based on the Funds of Knowledge approach. Culture \& Psychology, 20(1), 31-48. http://dx.doi.org/10.1177/1354067X13515934

Falchikov, N., \& Boud, D. (1989). Student self-assessment in higher education: A meta-analysis. Review of Educational Research, 59(4), 395-430. http://dx.doi.org/10.3102/0034654305900439

Forbes, D. (2005). Footprints: Participant perspectives informing pedagogy for asynchronous online discussion in initial teacher education. (Doctoral dissertation). The University of Waikato, New Zealand. Retrieved from http://researchcommons.waikato.ac.nz/handle/10289/7108

Forbes, D. (2012). Footprints: Participant perspectives informing pedagogy for asynchronous online discussion in initial teacher education. Unpublished doctoral dissertation, University of Waikato, Hamilton, New Zealand. Retrieved from http://researchcommons.waikato.ac.nz/handle/10289/7108

Foucault, M. (2007). Security, territory, population: Lectures at the Collège de France. 1977-1978 (G. Burchell, Trans.). Basingstoke, UK: Palgrave Macmillan.

Gee, J., Hull, G., \& Lankshear, C. (1996). The new work order: Behind the language of the new capitalism. Sydney: Allen \& Unwin

Gikandi, J., Morrow, D., \& Davis, N. (2011). Online formative assessment in higher education: A review of the literature. Computers \& Education, 57(4), 2333-2351. http://dx.doi.org/10.1016/j.compedu.2011.06.004

Gipps, C. (1994) Beyond testing: Towards a theory of educational assessment. London: The Falmer Press.

Giroux, H. A. (2003). Selling out higher education. Policy Futures in Education, 1(1), 179-200. http://dx.doi.org/10.2304/pfie.2003.1.1.6

Glasson, T. (2008). Improving student achievement through assessment for learning. Curriculum Leadership, 6(31). Retrieved from http://www.curriculum.edu.au/leader/improving_student_achievement,25374.html?issueID=11603

Hodgson, P., \& Pang, M. (2012). Effective formative e-assessment of student learning: A study on a statistics course. Assessment \& Evaluation in Higher Education, 37(2), 215-225. http://dx.doi.org/10.1080/02602938.2010.523818

Hodkinson, P., Biesta, G., \& James, D., (2008). Understanding learning culturally: Overcoming the dualism between social and individual views of learning. Vocations and Learning, 1(1), $27-47$. http://dx.doi.org/10.1007/s12186-007-9001

Hung, R. (2014). Learning as existential engagement with/in place: Departing from Vandenberg and the Reams. Educational Philosophy and Theory, 46(10), 1130-1142. http://dx.doi.org/10.1080/00131857.2013.799997

James, D., \& Biesta. G. (2007). Improving learning cultures in further education. London: Routledge.

James, M., McCormick, R., Black, P., Carmichael, P., Drummond, M-J., Fox, A., ... Wiliam, D. (2007). Improving learning how to learn: Classrooms, schools and networks. London: Routledge.

Jarvis, P. (2006). Towards a comprehensive theory of human learning. London: Routledge.

Johnson-Glenberg, M. (2010). Embedded formative e-assessment: Who benefits, who falters? Educational Media International, 47(2), 153-171. http://dx.doi.org/10.1080/09523987.2010.492681

Jordan, S., \& Mitchell, T. (2009). e-Assessment for learning? The potential of short-answer free-text questions with tailored feedback. British Journal of Educational Technology, 40(2), 371-385. http://dx.doi.org/10.1111/j.1467-8535.2008.00928

Kibble, J., Johnson, T., Khalil , M., Nelson , L., Riggs , G., Borrero, J., \& Payer, A. (2011). Insights gained from the analysis of performance and participation in online formative assessment. Teaching and Learning in Medicine: An International Journal, 23(2), 125-129. http://dx.doi.org/10.1080/10401334.2011.561687

Klenowski, V. (2009). Assessment for learning revisited: An Asia-Pacific perspective. Assessment in Education: Principles, Policy and Practice, 16(3), 263-268.

http://dx.doi.org/10.1080/09695940903319646 
Lafuente, M., \& Remesal, A., \& Álvarez Valdivia, I., (2014). Assisting learning in e-assessment: A closer look at educational supports. Assessment \& Evaluation in Higher Education, 39(4), 443-460. http://dx.doi.org/10.1080/02602938.2013.848835

Lave, J. (2009). The practice of learning. In K. Illeris (Ed.), Contemporary learning theories (pp. 200208). London: Routledge.

Lave, J., \& Wenger, E. (1991). Situated learning. Legitimate peripheral participation. London: Cambridge University Press.

Lin, J.-W., \& Lai, Y.-C. (2013). Harnessing collaborative annotations on online formative assessments. Educational Technology \& Society, 16(1), 263-274. Retrieved from http://www.ifets.info/journals/16_1/23.pdf

Lodge, C. (2002). 'Learning is something you do to children': Discourses of learning and student empowerment. Improving Schools, 5(1), 21-35. http://dx.doi.org/10.1177/136548020200500106

Mackey, T., Derr, D., \& O’Connor, E. (2009). Cost-effective strategies for developing formative assessments in online workplace training. International Journal of Advanced Corporate Learning, 2(4), 44-49. Retrieved from http://editlob.org/p/45710/

Miller, T. (2009). Formative computer-based assessment in higher education: The effectiveness of feedback in supporting student learning. Assessment \& Evaluation in Higher Education, 34(2), 181192. http://dx.doi.org/10.1080/02602930801956075

Nicol, D. (2009). Assessment for learner self-regulation: Enhancing achievement in the first year using learning technologies. Assessment \& Evaluation in Higher Education, 34(3), 335-352. http://dx.doi.org/10.1080/02602930802255139

Niedwiecki, A. (2013). Teaching for lifelong learning: Improving the metacognitive skills of law students through more effective formative assessment techniques. Capital University Law Review, 40(149), 149-193. http://dx.doi.org/10.1145/2460296.2460345

Palmer, E., \& Devitt, P. (2014) The assessment of a structured online formative assessment program: A randomised controlled trial. Palmer and Devitt BMC Medical Education, 14(8), 1-10. Retrieved from http://www.biomedcentral.com/content/pdf/1472-6920-14-8.pdf

Peters, M. (2009). Education, enterprise culture and the entrepreneurial self: A Foucauldian Perspective. Journal of Educational Enquiry, 2(2), 58-71.

Prosser, M., \& Trigwell, K. (1999). Understanding learning and teaching: The experience in higher education. Buckingham: The Society for Research into Higher Education \& Open University Press

Pryor, J., \& Crossouard, B. (2005, September). A sociocultural theorization of formative assessment. Paper presented at the Sociocultural Theory in Educational Research and Practice Conference, Manchester, UK. Retrieved from http://orgs.man.ac.uk/projects/include/experiment/pryor_crossouard.pdf

Pryor, J., \& Crossouard, B. (2008, December). Formative assessment - reconceptualizing disciplinary practices, identities and pedagogies? Paper presented at the Society for Research into Higher Education Annual Conference. Liverpool, UK. Retrieved from https://www.sussex.ac.uk/webteam/gateway/file.php?name=john-pryor-and-barbara-crossouardpaper---formative-assessment.pdf\&site $=41$

Pryor, J., \& Crossouard, B. (2010). Challenging formative assessment: Disciplinary spaces and identities. Assessment \& Evaluation in Higher Education, 35(3), 265-276. http://dx.doi.org/10.1080/02602930903512891

Sawyer, K. (2002). Unresolved tensions in sociocultural theory: Analogies with contemporary sociological debates. Culture and Psychology, 8(3), 283-305. Retrieved from http://lchc.ucsd.edu/mca/Tensions.pdf

Stiggins, R. (1991). Assessment literacy. Phi Delta Kappan, 72(7), 534-539.

Stiggins, R. (2005). What a difference a word makes. Assessment for learning rather than assessment of learning helps students succeed. Journal of Staff Development, 27(1), 10-14. Retrieved from http://ati.pearson.com/downloads/What-a-difference-a-word-makes.pdf

Stiggins, R. (2014). Improve assessment literacy outside of schools too. Phi Delta Kappan, 96(2), 67-72. http://dx.doi.org/10.1177/0031721714553413

Stödberg, U. (2012). A research review of e-assessment. Assessment \& Evaluation in Higher Education, 37(5), 591-604. http://dx.doi.org/10.1080/02602938.2011.557496

Turkle, S. (1996). Life on the screen. Identity in the age of the internet. London: Weidenfeld and Nicolson. 
Vaden-Goad, R. (2009). Leveraging summative assessment for formative purposes. College Teaching, 57(3), 153-155. http://dx.doi.org/10.3200/CTCH.57.3.153-155

van der Pol, J., van den Berg, B. A. M., Admiraal, W. F., \& Simons, P. R. J. (2008). The nature, reception, and use of online peer feedback in higher education. Computers \& Education, 51(4), $1804-$ 1817. Retrieved from http://dspace.library.uu.nl/handle/1874/29790

Velan, G., Jones, P., McNeil, P., \& Kumar, R. (2008). Integrated online formative assessments in the biomedical sciences for medical students: Benefits for learning. BMC Medical Education, 8(52). http://dx.doi.org/10.1186/1472-6920-8-5

Walker, D., Topping, K., \& Rodrigues, S. (2008). Student reflections on formative e-assessment: Expectations and perceptions. Learning, Media and Technology, 33(3), 221-234. http://dx.doi.org/10.1080/17439880802324178

Wenger, E. (2011). Communities of practice: A brief introduction. Retrieved from http://hdl.handle.net/1794/11736

Wertsch, J., del Rio, P., \& Alvarez, A. (1995). Sociocultural studies: History, action, and mediation. In J. Wertsch, P. del Rio \& A. Alvarez (Eds.), Sociocultural Studies of Mind (pp. 1-34). Cambridge, MA: University of Cambridge Press.

Wiliam, D. (2007). What does research say the benefits of formative assessment are? Assessment Research Brief. National Council of Teachers of Mathematics 1-3. Retrieved from http://www.nctm.org/uploadedFiles/Research_News_and_Advocacy/Research/Clips_and_Briefs/Rese arch brief_05_-_Formative_Assessment.pdf

Wiliam, D. (2011). Embedded formative assessment. Bloomington, IN: Solution Tree Press.

Wiliam, D. \& Black, P. J. (1996). Meanings and consequences: A basis for distinguishing formative and summative functions of assessment? British Educational Research Journal, 22(5), 537-548. Retrieved from http://www.jstor.org/stable/1501668

Wolsey, T. (2008). Efficacy of instructor feedback on written work in an online program. International Journal on E-Learning, 7(2), 311-329. Retrieved from http://www.editlib.org/index.cfm?CFID=5664581\&CFTOKEN=39387119\&fuseaction=Reader.View Abstract\&paper_id=23564

Corresponding author: Jennifer Charteris, jcharte5@une.edu.au

Australasian Journal of Educational Technology (c) 2016.

Please cite as: Charteris, J., Quinn, F., Parkes, M., Fletcher, P., \& Reyes, V. (2016). e-Assessment for learning and performativity in higher education: A case for existential learning. Australasian Journal of Educational Technology, 32(3), 112-122. 